\title{
Review \\ Diagnosis and treatment of severe sepsis
} Yann-Erick Claessens ${ }^{1-3}$ and Jean-François Dhainaut ${ }^{1-3}$

\author{
${ }^{1}$ Pôle Réanimations-Urgences, Hôpital Cochin, rue du Faubourg Saint-Jacques, 75679 Paris Cedex 14, Paris, France \\ 2Paris Descartes University, rue de l'école de Médecine, 75270 Paris Cedex 06, Paris, France \\ ${ }^{3} Y-E C$ and J-FD contributed equally to this work.
}

Corresponding author: Jean-François Dhainaut, president@univ-paris5.fr

Published: 19 December 2007

This article is online at http://ccforum.com/content/11/S5/S2

(c) 2007 BioMed Central Ltd
Critical Care 2007, 11(Suppl 5):S2 (doi:10.1186/cc6153)

worldwide and are focused on global improvement in practices whose primary goal it is to reduce sepsis-related death. As a consequence of the recommendations, a trend toward decreasing mortality has been observed during the past few years.

Difficulties remain, however, in applying all of the procedures recommended by the experts. This article summarizes the main proposals raised by the Surviving Sepsis Campaign and focuses on the difficulties associated with applying these guidelines in an appropriate time frame. the difficulties associated with making a proper diagnosis and supplying adequate treatment promptly to septic patients.

\section{Introduction}

Severe sepsis and septic shock are currently among the most common causes of morbidity and mortality in intensive care, and their incidences have increased during the past decade as the population has aged $[1,2]$. The emergency department (ED), where patients are treated for community-acquired infection, many of whom require intensive care unit (ICU) management [3], has been identified as a setting in which these syndromes and their outcomes may readily be observed.

Despite dramatic improvements in diagnostic and treatment procedures, mortality rates among patients with sepsis remained unchanged from the 1960 s through to the late 1990s. Diagnostic algorithms have therefore been developed to identify at-risk populations, and professional societies have worked to implement treatment procedures that focus efforts on early intervention. The Surviving Sepsis Campaign proposed management procedures that differentiate between 'resuscitation bundles' for the first 6 hours and 'management bundles' to be applied until the end of the 24th hour [4]. These procedure recommendations have been disseminated

\section{Diagnosis of sepsis and severity assessment}

Definitions of sepsis, severe sepsis, and septic shock were proposed 15 years ago. They were based on expert advice and used criteria that identify progression of the infection along with appropriate responses [5]. However, these criteria are clearly inadequate in terms of allowing detection of severe infections in routine daily practice. A study of a large multicenter cohort of ICU patients with infection [6] concluded that simply categorizing an infectious process as 'sepsis' or 'severe sepsis' did not predict prognosis. A high score indicating a septic condition did not necessarily predict a patient's outcome, even though that outcome might be affected by sepsis-related organ dysfunction.

With regard to patients presenting at the ED because of community-acquired pneumonia (CAP), a recent report from Dremsizov and coworkers [7] illustrated the limited value of the well established criteria for 'systemic inflammatory response syndrome' (SIRS) in predicting outcome. That work emphasizes the inability of the SIRS designation to identify which infected patients were at risk for developing severe sepsis or shock. These findings prompted experts to propose new scoring systems aimed at identifying patients who are at

CAP = community-acquired pneumonia; ED = emergency department; EGDT = early goal-directed therapy; ICU = intensive care unit; MEDS = Mortality in Emergency Department Sepsis; rhAPC = recombinant human activated protein $\mathrm{C} ; \mathrm{ScvO}_{2}=$ central venous oxygen saturation; SIRS $=$ systemic inflammatory response syndrome. 
risk for developing severe conditions related to infection. Shapiro and coworkers developed the Mortality in Emergency Department Sepsis (MEDS) score to predict 28-day [8] and 1-year [9] outcomes in patients presenting at an ED with infection, and calculation of this score requires data that are immediately available in the ED. Despite its ability to predict all-cause death in the study population, the accuracy of the MEDS score has not been tested at the individual patient level; its use at the bedside has not been evaluated, and therefore this tool should not be used in decisions regarding triage and ICU referral [10]. Most of the other newly developed scoring systems appear to have only marginal utility in daily routine practice because they require microbiologic identification and 24-hour clinical evaluation; hence, they lack the immediacy that is required for decision making in emergency medicine [6]. To date, the Pneumonia Severity Index is the only scoring system that is considered to help physicians to assess severity of illness in the ED [11]. Using this score at the bedside allows better triage of lowrisk patients [12-14], but it does not alter outcomes in more severe pneumonia [15], in which it is only slightly more effective than the inadequate SIRS classification [7].

Evaluation of biologic factors also may help in determining the severity of illness. Cady and coworkers [16] proposed use of the arterial blood lactate level to identify patients with severe illness and to assess the severity of sepsis. The Surviving Sepsis Campaign Management Guidelines Committee [4], and the American College of Chest Physicians and the Society of Critical Care Medicine Consensus Conference Committee [17] have also proposed guidelines that help to identify those patients who are at greater risk for sepsis. Recent reports from Shapiro [18] and Nguyen [19] and their colleagues have emphasized the importance of lactate clearance in identifying those patients who will respond to treatment and have a favorable outcome. Lactate clearance was shown to be a better prognostic factor than a single lactate determination performed on ED admission [18,19]. However, a single venous lactate measurement above 4 $\mathrm{mmol} / \mathrm{l}$ predicted short-term and in-hospital risk for death in patients presenting at the ED with suspected infection [20], even in those with normal arterial blood pressure [21]. A single lactate dosage is thus a valuable tool that may facilitate early detection of at-risk patients. Plasma procalcitonin may also be valuable in this setting. Procalcitonin is a more specific test than C-reactive protein [22] and interleukin-6, and can help the physician to detect sepsis [23]. Higher levels of procalcitonin are sufficiently specific to identify those septic patients who will develop severe sepsis, but it is not sensitive enough for routine use in ED triage [24].

\section{Antibiotics: fast and fitted}

It is clear that the site of infection should be managed promptly in patients with severe infection, including emergency surgery when applicable. However, efforts should also focus on early and carefully controlled antimicrobial therapy.
Minimizing the delay between admission and beginning antimicrobial treatment is key to achieving a successful outcome.

The potential influence of delayed antibiotic therapy was first evaluated in patients with CAP. In a series of 18,209 Medicare patients older than 65 years admitted because of CAP [25], the antibiotic regimen used saved lives when the first dose was administered before hour 4 after admission. Of note, fewer than $50 \%$ of patients received antibiotics during the first 4 hours in this study and as many as 17\% received antimicrobial treatment after hour 6 . Those patients in whom administration of antimicrobial agents was delayed were elderly people with an atypical CAP presentation, or they exhibited clinical features inconsistent with a diagnosis of sepsis, such as the absence of fever and altered mental status [26] (specifically, patients in whom the diagnosis of infection was not obvious). Such a lack of aggressive and early antimicrobial therapy has been identified in various settings in which patients were being treated for such conditions as meningitis, cancer, CAP, and nosocomial pneumonia [27-33]. A recent retrospective analysis quantified the impact of delayed antimicrobial treatment in patients with severe sepsis. Kumar and coworkers [34] demonstrated that every additional hour without antibiotics increased the risk for death in hypotensive septic patients by $7.6 \%$ during the first 6 hours. Early antibiotic therapy has been incorporated into the Surviving Sepsis Campaign recommendations [35], and we expect compliance with this component of the guidelines to increase from its current low level [36].

The focus of infection is sometimes difficult to ascertain, but treatment must effectively target the responsible pathogen, from among a wide range of potentially etiologic agents [37]. Initial selection of an antimicrobial agent with good activity against the causative organism is crucial for survival. A prospective evaluation of sepsis [38] emphasized that, other than comorbidity, the factor most strongly associated with death was ineffectiveness of antimicrobial treatment against the micro-organism identified in blood cultures. Several large reports corroborated the relation between ineffective antibiotic treatment and poor prognosis. Consequently, broadspectrum antibiotics have been recommended, and the agent selected should provide coverage against the microorganisms that are usually involved in the suspected focus of infection [35]. Supportive clinical evidence for use of broadspectrum antibiotics will probably remain sparse [36], but effective antimicrobial management requires good microbiologic sense.

Adherence to such guidelines regarding use of antibiotics may positively influence prognosis [39], but efforts to improve detection of pathogens should continue because enhanced specificity allows one to focus treatment on the responsible micro-organism and so limit the spectrum of coverage. The usual microbiologic techniques of detection may lack effectiveness. The use of urine antigens to Streptococcus 
pneumoniae and Legionella pneumophila type 1 can help in patients with pneumonia. Apart from their good sensitivity, the presence of these antigens can be detected long after an infection and, in the case of pneumoccocal related infection, may reflect carriage of the micro-organism in the upper respiratory tract [40]. Sensitive genomics tools are now available to detect both bacteria and viruses, and multiplex platforms allow screening of a wide range of micro-organisms [41]. The position of these techniques in the diagnostic armamentarium is yet to be defined, but efforts to improve antimicrobial therapy must continue so that our practices and therefore outcomes may be improved in the future.

\section{Fluid loading}

Among the symptomatic treatments, need for hemodynamic management is the most apparent, but modalities continue to be discussed and the scientific literature abounds with studies in this area. Efficient restoration of circulating blood volume is the primary goal of resuscitation in septic patients [42]. Albumin was the first product to be broadly used for intravenous fluid loading, but a meta-analysis comparing albumin with other fluid loading agents [43] identified an increased risk for death among patients who received albumin for supportive treatment during shock. However, subgroup analysis (septic patients with hypoalbuminemia) [44] revealed a trend toward greater efficiency of fluid loading with albumin. The cost-benefit balance is another factor that has restricted use of albumin, but in their recent report Guidet and colleagues [45] indicated that albumin infusion was potentially cost-effective in patients with sepsis. Thus, use of albumin should be considered with caution; it currently lacks the support needed for it to be recommended for use in patients with septic shock.

Transfusion of packed red cells may also be considered in septic patients because transfused hemoglobin may contribute to improved oxygen transport and delivery. Few controlled studies have tested this option, however, and it has been reported that liberal transfusion is potentially ineffective $[46,47]$. Since the publication of the findings of Rivers and coworkers [48], use of packed red cells has been regarded as a valuable approach to improving tissue oxygenation, but the specific indications for transfusion of packed red cells in this setting remain unclear.

Although controversy persists in this area, preferential use of crystalloids rather than colloids is supported by the available literature. For the same amount of volume expansion, there is no difference between these two treatments in terms of ejection stroke volume or oxygen delivery [49]. Systematic reviews and meta-analyses that included patients with sepsis and other types of patients concluded that crystalloids and colloids were generally similar in effect; an exception was one study that identified an advantage for crystalloids [50]. This finding received support from a randomized trial [51] that found that patients with septic shock receiving colloids had greater renal impairment. A recent study [52] was conducted to compare colloid with crystalloid volume resuscitation, with the aim being to identify the safest choice for use in patients with sepsis. This study, which employed a prospective randomized multicenter design, compared the influence on outcome of Ringer's lactate versus hydroxyethyl starch and of intensive versus conventional insulin therapy in patients with severe sepsis and septic shock. Experts have already criticized this study on the grounds that its design confounds applicability of the findings to routine daily care [53]. To summarize, although infusing fluids is a cornerstone of supportive care during sepsis, the optimal modalities and volume are difficult to determine and choices should be driven by objectives in the individual patient [48].

\section{Vasoactive drugs}

A solid rationale explains the utilization of vasopressors in daily practice [54], but the few comparative studies and the combination of different molecules account for their practical selection. Combining norepinephrine (noradrenaline) and dobutamine improved hemodynamic parameters of hepatosplanchnic circulation [55] but required invasive monitoring procedures, without clinical benefit. Dopamine and epinephrine are vasoconstrictors that also increase cardiac output, but their metabolic effects may be harmful [56,57]. In addition, use of vasopressors has been associated with poorer outcomes in septic patients, but their influence on mortality was unclear [58].

To assist physicians in their use of vasoactive drugs, professional associations have proposed guidelines that allow an opportunity to administer epinephrine or a combination of norepinephrine and dobutamine to more severely ill patients [4]. A recently reported study [59] indicated that these two strategies were equivalent in terms of both efficacy and safety. Interest in vasopressin is reflected in a growing number of publications, but the available evidence does not allow its integration into a global therapeutic scheme. However, recent data [60] may justify reconsideration of vasopressin in severe sepsis management guidelines in the near future. The VAsopressin in Septic Shock Trial (VASST) study [61] is currently comparing vasopressin with norepinephrine as initial vasopressor in septic shock patients. Because the study is not yet completed, no analysis or definite conclusions can yet be drawn from this trial.

Whichever drug is selected, introduction of vasopressors should be considered after optimal fluid loading; these agents may allow therapies to be applied earlier and more aggressively in order to improve physiological parameters and ultimately outcomes $[48,62]$.

\section{Applying early goal-directed therapy}

In the initial management of patients with sepsis, improving physiological parameters such as blood pressure and tissue 
oxygen delivery is a clear goal, as has been emphasized by experts since the late 1990s [63]. Previous studies underscored that applying an early goal-directed therapy (EGDT) approach could improve survival. The landmark study conducted by Rivers and coworkers [48] emphasized this concept in the field of sepsis. Its publication in 2001 prompted a debate in basic medical practice centered on the question, is it possible to improve outcomes in septic patients by increasing tissue oxygenation parameters during the first 6 hours of management?

The protocol proposed by Rivers and coworkers involves attainment of physiological levels of hemodynamic parameters (arterial blood pressure and central venous oxygen saturation $\left[\mathrm{ScvO}_{2}\right]$, by using fluid loading, vasopressors, packed red cells, and early initiation of mechanical ventilation) as rapidly as possible. The overwhelmingly positive results of this EGDT study prompted a number of ED and ICU teams to change their daily care in accordance with the study protocol. Some papers [62,64-66] reported partial or absolute adherence to the procedures evaluated by Rivers and coworkers. Others proposed adapting the procedure to their medical system with either less aggressive therapy or by forming 'sepsis teams' specifically tasked with managing patients with severe infection [67-72]. The overall result of these reports was a trend toward improved outcomes in septic patients [73].

However, these findings have been tempered by a number of barriers. Not all EDs have access to the same equipment, and ability to monitor hemodynamic parameters invasively varies widely [74]. Another unresolved issue is that not all ED physicians have the necessary resuscitation skills to administer optimal treatment, as observed in ICUs [75]. Additionally, a number of recent reports have identified the fact that EDs are increasingly overburdened. This can compromise the quality of care delivered to patients, especially those who require highly technical care that many ED physicians do not have time to practice because of everincreasing numbers of patients [76-78].

Finally, studies are now emerging that indicate how few of the recommendations have been implemented. Early administration of antimicrobial therapy was poorly adhered to, even in recent reports. In these, although the Surviving Sepsis Campaign proposals were implemented, the mean delay to first infusion of antibiotics remained in excess of 3 hours [62], and as many as $68 \%$ of patients did not receive their first dose within this period [79]. Only a few EGDT validation studies have been conducted in EDs applying aggressive treatment outside the ICU. However, even in those EDs, mortality sometimes remained at $31 \%$ before and after the institution of procedures to improve coordination between ED and ICU [80]. In addition, effort should be maintained after the initiation of an EGDT strategy because performance dramatically decreased after initial implementation [81,82].
In addition to the pragmatism of this therapeutic approach, the optimal tools with which to evaluate attainment of physiological goals have also been subject to debate. Although $\mathrm{ScvO}_{2}$ is a valuable parameter when it is abnormal, it may be in the normal range even in severely septic patients [73]. The hemodynamic presentation, of which there are many, depends on comorbidities and stage of sepsis [83]. In addition to $\mathrm{ScvO}_{2}$, central venous pressure may also provide useful information. A low central venous pressure indicates hypovolemia, and a high central nervous pressure with a low $\mathrm{ScvO}_{2}$ indicates myocardial suppression or mismatch of supply and demand. In any clinical situation, the findings must be interpreted alongside other clinical data. Other indicators may help, and systolic volume and pulse pressure variation of $10 \%$ or above also provide valuable information regarding blood volume [84]. Relatively liberal use of packed red cells to improve $\mathrm{ScvO}_{2}$ may be offset by its potential harm $[46,47]$ but in the setting of severe sepsis and septic shock the theoretical risks appear balanced by the benefits in terms of tissue oxygenation [85]. Although use of central venous pressure and $\mathrm{ScvO}_{2}$ to evaluate attainment of physiologic goals can be debated [73], it is clear that defining reasonable goals to treat sepsis is important whatever the local organization and the available means to achieve those objectives are [86].

\section{Adjunctive therapies}

For the past two decades therapeutic trials attempting to elicit a change in the host response to infection have failed to improve patients' conditions despite positive preclinical data [87-91]. However, the results of two recent studies have led to a more promising approach to this problem with recombinant human activated protein $\mathrm{C}$ (rhAPC) and low-dose steroids. The hemodynamic effects of steroids have been widely discussed since their use was found to allow early withdrawal of vasopressor treatment in a prospective doubleblinded, multicenter study [92]. The positive effects of steroids on adrenergic receptor cycling and sodium and water balance have been proposed as explanations for this efficacy. Their anti-inflammatory role as well as their anticoagulant effect, caused by limiting membrane expression of tissue factor, may contribute to the clinical benefit. A major difficulty lies in defining adrenal deficiency in septic shock patients, and a number of definitions have thus far been used. $A$ recent retrospective multicenter cohort study conducted by the Corticus study group [93] emphasized the importance of cortisol variation after corticotropin stimulation. That study additionally raised the possibility of a deleterious effect of etomidate on hormonal response and outcome, a concern that was previously reported by others [94]. This specific point is still subject to debate [95]. Efforts are currently being made to define the best strategy for use of steroids during sepsis.

The efficacy of rhAPC has been tested in a large multicenter study, the results of which have been widely debated. This 


\section{Emergency procedures: 90 minutes (in the absence of immediate vital threat)}
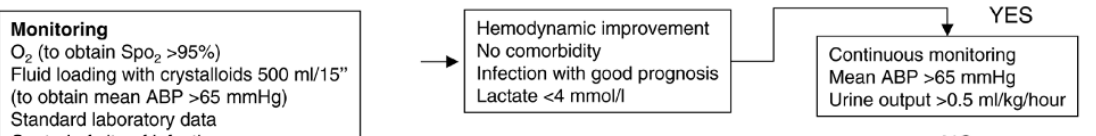

NO

\begin{tabular}{|lll|}
\hline \multicolumn{2}{|c|}{ 2. Intensive care: 6 hours (objectives and means) } \\
\hline $\begin{array}{l}\text { Means } \\
\text { Arterial and central venous lines } \\
\text { Mechanical ventilation }\end{array}$ & $\begin{array}{l}\text { Laboratory data (lactate, ACTH test) } \\
\text { Steroids infusion }\end{array}$ & $\begin{array}{c}\text { Microbiology } \\
\text { Control infection }\end{array}$ \\
\hline
\end{tabular}

\begin{tabular}{|c|c|c|c|c|c|}
\hline $\begin{array}{l}\text { Fluid loading } \\
\text { Norepinephrine }\end{array}$ & $\stackrel{\mathrm{NO}}{\longleftarrow}$ & $\begin{array}{l}\text { No clinical feature of hypoperfusion } \\
+ \text { mean } A B P>65 \mathrm{mmHg} \\
+ \text { urine output }>0.5 \mathrm{ml} / \mathrm{kg} / \mathrm{hour}\end{array}$ & $\mathrm{ScvO}_{2}>70 \%$ & $\stackrel{\mathrm{NO}}{\longrightarrow}$ & $\begin{array}{c}\text { RBC transfusion ( } \mathrm{Hb}>80 \mathrm{~g} / \mathrm{l}) \\
\text { Fluid loading } \\
\text { Dobutamine, epinephrine } \\
\text { (depending on monitoring) }\end{array}$ \\
\hline \multicolumn{6}{|c|}{ 3. Treatment adaptation } \\
\hline \multicolumn{2}{|c|}{ Maintain objectives } & \multicolumn{4}{|c|}{$\begin{array}{l}\text { - Consider steroids withdrawal (if positive response to ACTH test) } \\
\text { - Consider vasopressin (if norepinephrine is inefficient) } \\
\text { - Consider decreasing level of care (if objectives are achieved) }\end{array}$} \\
\hline
\end{tabular}

Management of severe sepsis in adults in the absence of an immediate life-threatening condition. ABP, arterial blood pressure; ACTH, adrenocorticotropic hormone; $\mathrm{Hb}$, hemoglobin; RBC, red blood cell; $\mathrm{ScvO}_{2}$, central venous oxygen saturation; $\mathrm{SpO}$, pulse oximetry. Reproduced with permission from Marquis S, Roupie E: Prise en charge précoce du choc septique aux urgences/Early management of septic shock in emergency department. Rèanimation 2006, 15:507-513.

compound was initially designed to compensate for a deficit in the natural anticoagulant protein $\mathrm{C}$ during sepsis, and thus it limited organ failures and improved the survival of septic shock patients [96]. Since then a number of studies have demonstrated that it has additional beneficial effects on complex interactions with inflammation, innate immunity, and apoptosis [97,98]. rhAPC also protected animals and healthy volunteers from hypotension after lipopolysaccharide challenge. A similar finding was also reported in the PROWESS (Recombinant Human Activated Protein C Worldwide Evaluation in Severe Sepsis) study, with more rapid improvement in hypotension and vasopressor withdrawal [99]. These clinical effects could be related to endocrine modulation (adrenomedullin was implicated in this regard) and vasoactive capacity. Mechanisms, efficacy, and safety of rhAPC are discussed in other reviews included in this supplement.

Despite the strong evidence base, use of adjunctive therapies has remained sparse in the setting of sepsis. Questionnaire surveys have attested to the under-use of such adjunctive therapies. Once again, the need for medical adherence to new therapies must be promoted by implementation of local guidelines that are inspired by the recommendations of the Surviving Sepsis Campaign (Figure 1).

\section{Improving standards of care}

New standards of care, such as low tidal volume mechanical ventilation and tight blood glucose control, have recently emerged and are now a cornerstone of treatment for critically ill patients. Low tidal volume $(\leq 6 \mathrm{ml} / \mathrm{kg})$ as compared with 'standard' mechanical ventilation $(12 \mathrm{ml} / \mathrm{kg})$ has improved survival in patients with acute respiratory distress syndrome in independent studies $[100,101]$. Two landmark studies by van den Berghe and colleagues [102,103] suggested that aggressive insulin therapy improved 30-day survival in critically ill surgical patients, and reduced morbidity indicators such as weaning from mechanical ventilation and hospital days in medical ICU patients. Whereas occurrence and management of hypoglycemia appeared irrelevant in the main papers and additional data, hypoglycemia has been identified as potentially causing harm by others [104]. Even if these standards are still discussed and do not specifically impact on sepsis, they may also contribute to quality-of-care improvement and finally to patients' successful outcome $[83,84]$.

\section{Conclusion}

Guidelines that were proposed through the Surviving Sepsis Campaign to improve outcome in septic patients are difficult to apply routinely in most EDs. Attempts to apply these procedures fully have varied widely; diagnosis may be problematic because of atypical or unspecific presentations, biomarkers are of little help at the start of treatment and are unspecific, supportive treatment often depends on local supply of resources, and specific devices are often absent in EDs for initial therapy and monitoring. Even adherence to early administration of antibiotic therapy is poor, with delays 
being common. Our goal is now to improve the level of care by applying evidence-based procedures.

\section{Competing interests}

J-FD was an investigator in the PROWESS study and is a consultant for Eli Lilly and Company. Y-EC declares that he has no competing interests.

\section{Acknowledgements}

We acknowledge Professor Alain Cariou for careful reading of the manuscript.

This article is part of Critical Care Volume 11 Supplement 5: Severe sepsis and drotrecogin alfa (activated). The full contents of the supplement are available online at http://ccforum.com/supplements/11/S5. Publication of the supplement has been sponsored by Eli Lilly and Company.

\section{References}

1. Angus DC, Linde-Zwirble WT, Lidicker J, Clermont G, Carcillo J, Pinsky MR: Epidemiology of severe sepsis in the United States: analysis of incidence, outcome, and associated costs of care. Crit Care Med 2001, 29:1303-1310.

2. Martin GS, Mannino DM, Eaton S, Moss M: The epidemiology of sepsis in the United States from 1979 through 2000. N Engl J Med 2003, 348:1546-1554.

3. Strehlow MC, Emond SD, Shapiro NI, Pelletier AJ, Camargo CA Jr: National study of emergency department visits for sepsis, 1992 to 2001. Ann Emerg Med 2006, 48:326-331.

4. Dellinger RP, Carlet JM, Masur $\mathrm{H}$, Gerlach $\mathrm{H}$, Calandra $\mathrm{T}$, Cohen J, Gea-Banacloche J, Keh D, Marshall JC, Parker MM, et al.; Surviving Sepsis Campaign Management Guidelines Committee: Surviving Sepsis Campaign guidelines for management of severe sepsis and septic shock. Crit Care Med 2004, 32:858873.

5. Bone RC: Sepsis, the sepsis syndrome, multiorgan failure: a plea for comparable definitions. Ann Intern Med 1991, 114: 332-333.

6. Alberti C, Brun-Buisson C, Chevret S, Antonelli M, Goodman SV, Martin C, Moreno R, Ochagavia AR, Palazzo M, Werdan K, et al.; European Sepsis Study Group: Systemic inflammatory response and progression to severe sepsis in critically ill infected patients. Am J Respir Crit Care Med 2005, 171:461468.

7. Dremsizov T, Clermont G, Kellum JA, Kalassian KG, Fine MJ, Angus DC: Severe sepsis in community-acquired pneumonia: when does it happen, and do systemic inflammatory response syndrome criteria help predict course? Chest 2006 , 129:968-978.

8. Shapiro NI, Wolfe RE, Moore RB, Smith E, Burdick E, Bates DW: Mortality in Emergency Department Sepsis (MEDS) score: a prospectively derived and validated clinical prediction rule. Crit Care Med 2003, 31:670-675.

9. Shapiro NI, Howell MD, Talmor D, Donnino M, Ngo L, Bates DW: Mortality in Emergency Department Sepsis (MEDS) score predicts 1-year mortality. Crit Care Med 2007, 35:192-198.

10. Carlet J: Early goal-directed therapy of septic shock in the emergency room: who could honestly remain skeptical? Crit Care Med 2006, 34:2842-2843.

11. Fine MJ, Auble TE, Yealy DM, Hanusa BH, Weissfeld LA, Singer $\mathrm{DE}$, Coley CM, Marrie TJ, Kapoor WN: A prediction rule to identify low-risk patients with community-acquired pneumonia. $\mathrm{N}$ Engl J Med 1997, 336:243-250.

12. Renaud B, Coma E, Labarere J, Hayon J, Roy PM, Boureaux $\mathrm{H}$, Moritz F, Cibien JF, Guerin T, Carre E, et al.; Pneumocom Study Investigators: Routine use of the Pneumonia Severity Index for guiding the site-of-treatment decision of patients with pneumonia in the emergency department: a multicenter, prospective, observational, controlled cohort study. Clin Infect Dis 2007, 44:41-49.

13. Carratala J, Fernandez-Sabe N, Ortega L, Castellsague X, Roson B, Dorca J, Fernandez-Aguera A, Verdaguer R, Martinez J, Manresa $F$, et al.: Outpatient care compared with hospitaliza- tion for community-acquired pneumonia: a randomized trial in low-risk patients. Ann Intern Med 2005, 142:165-172.

14. Aujesky D, Stone RA, Obrosky DS, Yealy DM, Auble TE, Meehan TP, Graff LG, Fine JM, Fine MJ: Using randomized controlled trial data, the agreement between retrospectively and prospectively collected data comprising the pneumonia severity index was substantial. J Clin Epidemio/ 2005, 58:357363.

15. Aujesky D, Auble TE, Yealy DM, Stone RA, Obrosky DS, Meehan TP, Graff LG, Fine JM, Fine MJ: Prospective comparison of three validated prediction rules for prognosis in communityacquired pneumonia. Am J Med 2005, 118:384-392.

16. Cady LD Jr, Weil MH, Afifi AA, Michaels SF, Liu VY, Shubin H: Quantitation of severity of critical illness with special reference to blood lactate. Crit Care Med 1973, 1:75-80.

17. Bone RC, Balk RA, Cerra FB, Dellinger RP, Fein AM, Knaus WA, Schein RM, Sibbald WJ: Definitions for sepsis and organ failure and guidelines for the use of innovative therapies in sepsis. The ACCP/SCCM Consensus Conference Committee. American College of Chest Physicians/Society of Critical Care Medicine. Chest 1992, 101:1644-1655.

18. Shapiro NI, Howell MD, Talmor D, Nathanson LA, Lisbon A, Wolfe RE, Weiss JW: Serum lactate as a predictor of mortality in emergency department patients with infection. Ann Emerg Med 2005, 45:524-528.

19. Nguyen HB, Rivers EP, Knoblich BP, Jacobsen G, Muzzin A, Ressler JA, Tomlanovich MC: Early lactate clearance is associated with improved outcome in severe sepsis and septic shock. Crit Care Med 2004, 32:1637-1642.

20. Trzeciak S, Dellinger RP, Chansky ME, Arnold RC, Schorr C, Milcarek B, Hollenberg SM, Parrillo JE. Serum lactate as a predictor of mortality in patients with infection. Intensive Care Med 2007, 33:970-977.

21. Howell MD, Donnino M, Clardy P, Talmor D, Shapiro NI. Occult hypoperfusion and mortality in patients with suspected infection. Intensive Care Med 2007, 33:1892-1899.

22. Simon L, Gauvin F, Amre DK, Saint-Louis P, Lacroix J: Serum procalcitonin and C-reactive protein levels as markers of bacterial infection: a systematic review and meta-analysis. Clin Infect Dis 2004, 39:206-217.

23. Harbarth S, Holeckova K, Froidevaux C, Pittet D, Ricou B, Grau GE, Vadas L, Pugin J, Geneva Sepsis Network: Diagnostic value of procalcitonin, interleukin-6, and interleukin-8 in critically ill patients admitted with suspected sepsis. Am J Respir Crit Care Med 2001, 164:396-402.

24. Hausfater P, Garric S, Ayed SB, Rosenheim M, Bernard M, Riou $B$ : Usefulness of procalcitonin as a marker of systemic infection in emergency department patients: a prospective study. Clin Infect Dis 2002, 34:895-901.

25. Houck PM, Bratzler DW, Nsa W, Ma A, Bartlett JG: Timing of antibiotic administration and outcomes for Medicare patients hospitalized with community-acquired pneumonia. Arch Intern Med 2004, 164:637-644.

26. Metersky ML, Sweeney TA, Getzow MB, Siddiqui F, Nsa W, Bratzler DW: Antibiotic timing and diagnostic uncertainty in Medicare patients with pneumonia: is it reasonable to expect all patients to receive antibiotics within 4 hours? Chest 2006, 130:16-21.

27. Proulx N, Frechette D, Toye B, Chan J, Kravcik S: Delays in the administration of antibiotics are associated with mortality from adult acute bacterial meningitis. QJM 2005, 98:291-298.

28. Iregui M, Ward S, Sherman G, Fraser VJ, Kollef MH: Clinical importance of delays in the initiation of appropriate antibiotic treatment for ventilator-associated pneumonia. Chest 2002, 122:262-268.

29. Mathevon T, Souweine B, Traore O, Aublet B, Caillaud D: ICUacquired nosocomial infection: Impact of delay of adequate antibiotic treatment. Scand J Infect Dis 2002, 34:831-835.

30. Miner JR, Heegaard W, Mapes A, Biros M: Presentation, time to antibiotics, and mortality of patients with bacterial meningitis at an urban county medical center. J Emerg Med 2001, 21: 387-392.

31. Kang Cl, Kim SH, Kim HB, Park SW, Choe YJ, Oh MD, Kim EC, Choe KW: Pseudomonas aeruginosa bacteremia: risk factors for mortality and influence of delayed receipt of effective antimicrobial therapy on clinical outcome. Clin Infect Dis 2003, 37:745-751. 
32. Lodise TP, McKinnon PS, Swiderski L, Ryback MJ: Outcomes analysis of delayed antibiotic treatment for hospital-acquired Staphylococcus aureus bacteremia. Clin Infect Dis 2003, 36: 1418-1423

33. Larche J, Azoulay E, Fieux F, Mesnard L, Moreau D, Thiery G, Darmon M, Le Gall JR, Schlemmer B: Improved survival of critically ill cancer patients with septic shock. Intensive Care Med 2003, 29:1688-1695.

34. Kumar A, Roberts D, Wood KE, Light B, Parrillo JE, Sharma S, Suppes R, Feinstein D, Zanotti S, Taiberg L, et al.: Duration of hypotension before initiation of effective antimicrobial therapy is the critical determinant of survival in human septic shock. Crit Care Med 2006, 34:1589-1596.

35. Bochud PY, Bonten M, Marchetti O, Calandra T: Antimicrobial therapy for patients with severe sepsis and septic shock: an evidence-based review. Crit Care Med 2004, 32: S495-S512.

36. Girard TD, Opal SM, Ely EW: Insights into severe sepsis in older patients: from epidemiology to evidence-based management. Clin Infect Dis 2005, 40:719-727.

37. Groeneveld ABJ, Thijs LG: Diagnosis: from clinical signs to haemodynamic evaluation. In Septic Shock. Edited by Dhainaut JF, Thijs LG, Park G. London, UK: WB Saunders; 2000:355-386.

38. Weinstein MP, Towns ML, Quartey SM, Mirrett S, Reimer LG, Parmigiani G, Reller LB: The clinical significance of positive blood cultures in the 1990s: a prospective comprehensive evaluation of the microbiology, epidemiology, and outcome of bacteremia and fungemia in adults. Clin Infect Dis 1997, 24: 584-602.

39. Mortensen EM, Restrepo MI, Anzueto A, Pugh JA: Antibiotic therapy and 48-hour mortality for patients with pneumonia. Am J Med 2006, 119:859-864.

40. Butler JC, Bosshardt SC, Phelan M, Moroney SM, Tondella ML, Farley MM, Schuchat A, Fields BS: Classical and latent class analysis evaluation of sputum polymerase chain reaction and urine antigen testing for diagnosis of pneumococcal pneumonia in adults. $J$ Infect Dis 2003, 187:1416-1423.

41. Kistler A, Avila PC, Rouskin S, Wang D, Ward T, Yagi S, Schnurr D, Ganem D, DeRisi JL, Boushey HA: Pan-viral screening of respiratory tract infections in adults with and without asthma reveals unexpected human coronavirus and human rhinovirus diversity. $J$ Infect Dis 2007, 196:817-825.

42. Vincent JL, Gerlach H: Fluid resuscitation in severe sepsis and septic shock: an evidence-based review. Crit Care Med 2004, 32:S451-S454.

43. Cochrane Injuries Group Albumin Reviewers: Human albumin administration in critically ill patients: systematic review of randomised controlled trials. BMJ 1998, 31:235-240.

44. Finfer S, Bellomo R, Boyce N, French J, Myburgh J, Norton R; SAFE Study Investigators: A comparison of albumin and saline for fluid resuscitation in the intensive care unit. $N$ Engl $J$ Med 2004, 350:2247-2256.

45. Guidet B, Mosqueda GJ, Priol G, Aegerter P: The COASST study: cost-effectiveness of albumin in severe sepsis and septic shock. J Crit Care 2007, 22:197-203.

46. Hebert PC, Wells G, Blajchman MA, Marshall J, Martin C, Pagliarello G, Tweeddale M, Schweitzer I, Yetisir E: A multicenter, randomized, controlled clinical trial of transfusion requirements in critical care. Transfusion Requirements in Critical Care Investigators, Canadian Critical Care Trials Group. N Engl J Med 1999, 340:409-417.

47. Silliman CC, Ambruso DR, Boshkov LK: Transfusion-related acute lung injury. Blood 2005, 105:2266-2273.

48. Rivers E, Nguyen B, Havstad S, Ressler J, Muzzin A, Knoblich B, Peterson E, Tomlanovich M; Early Goal-Directed Therapy Collaborative Group: Early goal directed therapy in the treatment of severe sepsis and septic shock. N Engl J Med 2001, 345: 1368-1377.

49. Alderson P, Schierhout G, Roberts I, Bunn F: Colloids versus crystalloids for fluid resuscitation in critically ill patients. Cochrane Database Syst Rev 2004, 4:CD000567.

50. Schierhout G, Roberts I: Fluid resuscitation with colloid or crystalloid solutions in critically ill patients: a systematic review of randomised trials. BMJ 1998, 316:961-964.

51. Schortgen F, Lacherade JC, Bruneel F, Cattaneo I, Hemery F, Lemaire $F$, Brochard L: Effects of hydroxyethylstarch and gelatin on renal function in severe sepsis: a multicentre randomised study. Lancet 2001, 357:911-916.
52. Reinhart K, Bloos F, Engel C, on behalf the German Competence Network Sepsis: Hydroxyethyl starch and Ringer's lactate for fluid resuscitation in patients with severe sepsis: results from the VISEP study [abstract 0818]. Intens Care Med 2006, S1: 213.

53. Zander R, Boldt J, Engelmann L, Mertzlufft F, Sirtl C, Stuttmann R: The design of the VISEP trial. Critical appraisal [in German]. Anaesthesist 2007, 56:71-77.

54. Beal RB, Hollenberg SM, Vincent JL, Parrillo JE: Vasopressor and inotropic support in septic shock: an evidence based review. Crit Care Med 2004, 32(suppl):S455-S465.

55. Hannemann L, Reinhart K, Grenzer O, Meier-Hellmann A, Bredle $\mathrm{DL}$ : Comparison of dopamine to dobutamine and norepinephrine for oxygen delivery and uptake in septic shock. Crit Care Med 1995, 23:1962-1970.

56. Jakob SM, Ruokonen E, Takala J: Effects of dopamine on systemic and regional blood flow and metabolism in septic and cardiac surgery patients. Shock 2002, 18:8-13.

57. Day NP, Phu NH, Bethell DP, Mai NT, Chau TT, Hien TT, White $\mathrm{NJ}$ : The effects of dopamine and adrenaline infusions on acidbase balance and systemic haemodynamics in severe infection. Lancet 1996, 348:219-223.

58. Levy MM, Macias WL, Vincent JL, Russell JA, Silva E, Trzaskoma $B$, Williams MD. Early changes in organ function predict eventual survival in severe sepsis. Crit Care Med 2005, 33:21942201.

59. Annane $D$, Vignon $P$, Renault $A$, Bollaert $P E$, Charpentier $C$, Martin C, Troche G, Ricard JD, Nitenberg G, Papazian L, et al.; CATS Study Group: Norepinephrine plus dobutamine versus epinephrine alone for management of septic shock: a randomised trial. Lancet 2007, 370:676-684.

60. Delmas A, Leone M, Rousseau S, Albanese J, Martin C: Vasopressin and terlipressin in septic shock patients. Crit Care 2005, 9:212-222.

61. Barrett LK, Singer M, Clapp LH: Vasopressin: mechanisms of action on the vasculature in health and in septic shock. Crit Care Med 2007, 35:33-40.

62. Sebat F, Johnson D, Musthafa AA, Watnik M, Moore S, Henry K, Saari M: A multidisciplinary community hospital program for early and rapid resuscitation of shock in nontrauma patients. Chest 2005, 127:1729-1743.

63. Task Force of the American College of Critical Care Medicine, Society of Critical Care Medicine: Practice parameters for hemodynamic support of sepsis in adult patients in sepsis. Crit Care Med 1999, 27:639-660.

64. Nguyen HB, Corbett SW, Clark RT, Cho T, Wittlake WA: Improving the uniformity of care with a sepsis bundle in the emergency department. Ann Emerg Med 2005, 46:S83.

65. Gaieski D, McCoy J, Zeserson E, Chase M, Goyal M: Mortality benefit after implementation of early goal directed therapy protocol for the treatment of severe sepsis and septic shock. Ann Emerg Med 2005, 46:S4.

66. Verceles A, Schwarcz RM, Birnbaum P, Mannam P, Patrick H: S.E.P.S.I.S: sepsis education plus successful implementation and sustainability in the absence of a rapid response team [abstract]. Chest 2005, 128:S181-S182.

67. Gao F, Melody T, Daniels DF, Giles S, Fox S: The impact of compliance with 6-hour and 24-hour sepsis bundles on hospital mortality in patients with severe sepsis: a prospective observational study. Crit Care 2005, 9:R764-R770.

68. Kortgen A, Niederprum $\mathrm{P}$, Bauer M: Implementation of an evidence-based 'standard operating procedure' and outcome in septic shock. Crit Care Med 2006, 34:943-949.

69. Armstrong R, Salfen SJ: Results of implementing a rapid response team approach in treatment of shock in a community hospital [abstract]. In Proceedings of the 43rd Annual Meeting of the Infectious Diseases Society of America; 6-9 October 2005; San Francisco, California. Arlington, Virginia: Infectious Diseases Society of America; 2005:154.

70. Micek ST, Roubinian N, Heuring T, Bode M, Williams J, Harrison C, Murphy T, Prentice D, Ruoff BE, Kollef MH: Before-after study of a standardized hospital order set for the management of septic shock. Crit Care Med 2006, 34:2707-2713.

71. Rogove $H$, Pyle K: Collaboration for instituting the surviving sepsis campaign in a community hospital [abstract]. Crit Care Med 2005, 33(suppl):110S.

72. Stenstrom R, Hollohan K, Nebre R, MacRedmond R, Grafstein E, 
Dodek P, Innes G, Hunte G, Harris D, Westman J, et al.: Impact of a sepsis protocol for the management of patients with severe sepsis and septic shock in the emergency department [abstract]. Can J Emerg Med 2006, 8:S16.

73. Otero RM, Nguyen HB, Huang DT, Gaieski DF, Goyal M, Gunnerson KJ, Trzeciak S, Sherwin R, Holthaus CV, Osborn T, et al.: Early goal-directed therapy in severe sepsis and septic shock revisited: concepts, controversies, and contemporary findings. Chest 2006, 130:1579-1595.

74. Yu DT, Black E, Sands KE, Schwartz JS, Hibberd PL, Graman PS, Lanken PN, Kahn KL, Snydman DR, Parsonnet J, et al.; Academic Medical Center Consortium Sepsis Project Working Group: Severe sepsis: variation in resource and therapeutic modality use among academic centers. Crit Care 2003, 7:R24-R34.

75. Angus DC, Shorr AF, White A, Dremsizov TT, Schmitz RJ, Kelley MA; Committee on Manpower for Pulmonary and Critical Care Societies (COMPACCS): Critical care delivery in the United States: distribution of services and compliance with Leapfrog recommendations. Crit Care Med 2006, 34:1016-1024.

76. McCaig LF, Burt CW: National Hospital Ambulatory Medical Care Survey: 2001 emergency department summary. Adv Data 2003, 335:1-29.

77. Trzeciak S, Rivers EP: Emergency department overcrowding in the United States: an emerging threat to patient safety and public health. Emerg Med J 2003, 20:402-405.

78. Kellermann AL: Crisis in the emergency department. $N$ Engl J Med 2006, 355:1300-1303.

79. De Miguel-Yanes JM, Andueza-Lillo JA, Gonzalez-Ramallo VJ, Pastor L, Munoz J: Failure to implement evidence-based clinical guidelines for sepsis at the ED. Am J Emerg Med 2006, 24: 553-559.

80. Levy MM, Pronovost PJ, Dellinger RP, Townsend S, Resar RK, Clemmer TP, Ramsay G: Sepsis change bundles: converting guidelines into meaningful change in behavior and cliniqal outcome. Crit Care Med 2004, 32:S595-S597.

81. Trzeciak S, Dellinger RP, Abate NL, Cowan RM, Stauss M, Kilgannon JH, Zanotti S, Parrillo JE: Translating research to clinical practice: a 1-year experience with implementing early goaldirected therapy for septic shock in the emergency department. Chest 2006, 129:225-232.

82. Beale R: Success with the sepsis bundles: going for gold. In Proceedings of the 19th Annual Congress of the European Society of Intensive Care Medicine; 24-27 September 2006; Barcelona, Spain. Brussels, Belgium: European Society of Intensive Care Medicine; 2006

83. Dhainaut JF, Schlemmer B, Monsallier JF, Huyghebaert MF, Brunet $F$, Villemant $D$, Carli A: Oxygen consumption during septic shock. Effects of inotropic drugs. Arch Int Physiol Biochim 1984, 92:S57-S64.

84. Michard F, Teboul JL Predicting fluid responsiveness in ICU patients: a critical analysis of the evidence. Chest 2002, 121: 2000-2008.

85. Rivers EP, Kruse JA, Jacobsen G, Shah K, Loomba M, Otero R, Childs $E W$. The influence of early hemodynamic optimization on biomarker patterns of severe sepsis and septic shock. Crit Care Med 2007, 35:2016-2024.

86. Sevransky JE, Nour S, Susla GM, Needham DM, Hollenberg S, Pronovost P: Hemodynamic goals in randomized clinical trials in patients with sepsis: a systematic review of the literature. Crit Care 2007, 11:R67.

87. Ziegler EJ, McCutchan JA, Fierer J, Glauser MP, Sadoff JC, Douglas $\mathrm{H}$, Braude Al: Treatment of gram-negative bacteremia and shock with human antiserum to a mutant Escherichia coli. N Engl J Med 1982, 307:1225-1230.

88. Fisher CJ Jr, Slotman GJ, Opal SM, Pribble JP, Bone RC, Emmanuel G, Ng D, Bloedow DC, Catalano MA; IL-1RA Sepsis Syndrome Study Group: Initial evaluation of human recombinant interleukin-1 receptor antagonist in the treatment of sepsis syndrome: a randomized, open-label, placebo-controlled multicenter trial. Crit Care Med 1994, 22:12-21.

89. Reinhart K, Menges T, Gardlund B, Harm Zwaveling J, Smithes M, Vincent JL, Tellado JM, Salgado-Remigio A, Zimlichman R, Withington $\mathrm{S}$, et al:: Randomized, placebo-controlled trial of the anti-tumor necrosis factor antibody fragment afelimomab in hyperinflammatory response during severe sepsis: The RAMSES Study. Crit Care Med 2001, 29:765-769.

90. Fisher CJ Jr, Agosti JM, Opal SM, Lowry SF, Balk RA, Sadoff JC,
Abraham E, Schein RM, Benjamin E: Treatment of septic shock with the tumor necrosis factor receptor:Fc fusion protein. The Soluble TNF Receptor Sepsis Study Group. N Engl J Med 1996, 334:1697-1702.

91. Abraham E, Reinhart K, Opal S, Demeyer I, Doig C, Rodriguez AL, Beale R, Svoboda P, Laterre PF, Simon S, et al.; OPTIMIST Trial Study Group: Efficacy and safety of tifacogin (recombinant tissue factor pathway inhibitor) in severe sepsis: a randomized controlled trial. JAMA 2003, 290:238-247.

92. Annane D, Sebille V, Charpentier C, Bollaert PE, Francois B, Korach JM, Capellier G, Cohen Y, Azoulay E, Troche G, et al.: Effect of treatment with low doses of hydrocortisone and fludrocortisone on mortality in patients with septic shock. JAMA 2002, 288:862-871.

93. Lipiner-Friedman D, Sprung CL, Laterre PF, Weiss Y, Goodman SV, Vogeser M, Briegel J, Keh D, Singer M, Moreno R, et al.; Corticus Study Group: Adrenal function in sepsis: the retrospective Corticus cohort study. Crit Care Med 2007, 35:1012-1018.

94. Jackson WL Jr: Should we use etomidate as an induction agent for endotracheal intubation in patients with septic shock?: a critical appraisal. Chest 2005, 127:1031-1038.

95. Ray DC, McKeown DW: Effect of induction agent on vasopressor and steroid use, and outcome in patients with septic shock. Crit Care 2007, 11:R56.

96. Bernard GR, Vincent JL, Laterre PF, LaRosa SP, Dhainaut JF, Lopez-Rodriguez A, Steingrub JS, Garber GE, Helterbrand JD, Ely $\mathrm{EW}$, et al:; Recombinant human protein $\mathrm{C}$ Worldwide Evaluation in Severe Sepsis (PROWESS) study group: Efficacy and safety of recombinant human activated protein $\mathrm{C}$ for severe sepsis. N Engl J Med 2001, 344:699-709.

97. Macias WL, Yan SB, Williams MD, Um SL, Sandusky GE, Ballard DW, Planquois JM: New insights into the protein $C$ pathway: potential implications for the biological activities of drotrecogin alfa (activated). Crit Care 2005, 9:S38-S45.

98. Kalil AC, Coyle SM, Um JY, LaRosa SP, Turlo MA, Calvano SE, Sundin DP, Nelson DR, Lowry SF: Effects of drotrecogin alfa (activated) in human endotoxemia. Shock 2004, 21:222-229.

99. Vincent JL, Angus DC, Artigas A, Kalil A, Basson BR, Jamal HH, Johnson G III, Bernard GR. Recombinant Human Activated Protein C Worldwide Evaluation in Severe Sepsis (PROWESS) Study Group: Effects of drotrecogin alfa (activated) on organ dysfunction in the PROWESS trial. Crit Care Med 2003, 31: 834-840.

100. The Acute Respiratory Distress Syndrome Network: Ventilation with lower tidal volumes as compared with traditional tidal volumes for acute lung injury and the acute respiratory distress syndrome. N Engl J Med 2000, 342:1301-1308.

101. Amato MB, Barbas CS, Medeiros DM, Magaldi RB, Schettino GP, Lorenzi-Filho G, Kairalla RA, Deheinzelin D, Munoz C, Oliveira $\mathrm{R}$, et al.: Effect of a protective-ventilation strategy on mortality in the acute respiratory distress syndrome. $N$ Engl $J$ Med 1998, 338:347-354.

102. van den Berghe $G$, Wouters $P$, Weekers F, Verwaest $C$, Bruyninckx F, Schetz M, Vlasselaers D, Ferdinande P, Lauwers $P$, Bouillon R: Intensive insulin therapy in the critically ill patients. $N$ Engl J Med 2001, 345:1359-1367.

103. van den Berghe G, Wilmer A, Hermans G, Meersseman W, Wouters PJ, Milants I, Van Wijngaerden E, Bobbaers H, Bouillon $\mathrm{R}$ : Intensive insulin therapy in the medical ICU. $N$ Engl J Med 2006, 354:449-461.

104. Malhotra A: Intensive insulin in intensive care. $N$ Engl J Med 2006, 354:516-518. 